\title{
ACTION OF HYPOPHYSEAL GROWTH AND THYROTROPHIC HORMONES IN THYROIDECTOMIZED RATS
}

\author{
BY \\ E. SALGADO* \\ Institut de Médecine et de Chirurgie Expérimentales, Université de Montréal, Montreal, Canada
}

(RECEIVED FOR PUBLICATION OCTOBER 29, 1954)

It has been shown (Selye, 1951b) that in unilaterally nephrectomized rats drinking 1 per cent. $\mathrm{NaCl}$, electrophoretically homogeneous preparations of growth hormone (STH) caused nephrosclerosis, polyuria, myocarditis, and hypertension. This syndrome very closely resembles that produced by desoxycorticosterone acetate (DCA).

However, one striking difference between the effects of STH and DCA is that the former stimulates somatic growth but causes no visible lesions of periarteritis nodosa in mesenteric vessels, while the latter produces marked periarteritic changes but no excess growth. We have already shown (Salgado, 1954a; Salgado and Selye, 1954) that in thyroparathyroidectomized animals both DCA and MAD fail to produce hypertension; myocardial and renal lesions are much diminished but nevertheless periarteritis nodosa is more severe than in the intact animals similarly treated. We have postulated that the absence of the thyroid is probably a condition that favours the appearance of periarteritic lesions (Salgado, 1954b).

The present experiment was devised to see if, in the absence of the thyroid, STH-treated rats would

\footnotetext{
* Present address: Research Division, Nepera Chemical Company, Yonkers, New York.
}

develop lesions of periarteritis nodosa. At the same time, we compared, at the same dose level, the effect of STH and thyrotrophic hormone (TTH), as small amounts of the latter are present in our preparation of STH as an impurity.

\section{Materials and Methods}

67 Sprague Dawley rats were subdivided into six groups (Table I). The right kidney was removed in all groups and thyroparathyroidectomy was performed in Groups II, V, and VI, at the beginning of the experiment.

STH (Armour R-285-183) was administered twice a day subcutaneously, dissolved in saline, the daily dose being $1 \mathrm{mg}$. $/ 50 \mathrm{mg}$. body-weight per day.

TTH (Armour P589-80) was given under the same conditions and at the same dose level as STH.

The animals received both Purina Fox Chow and 1 per cent. $\mathrm{NaCl}$ (as drinking fluid) ad lib.

Blood pressure measurements were made by the method of Friedman and Freed (1949). All animals were killed on the 28th day, except four in Group VI (killed on the 43rd day), and their organs were fixed in Susa for weighing and histological study. Sections were stained with haematoxylin and eosin as well as with the PAS procedure (McManus, 1948).

The data were statistically evaluated according to the method of Snedecor (1946).

TABLE I

ORGAN WEIGHTS IN RATS UNILATERALLY NEPHRECTOMIZED AND DRINKING 1 PER CENT. NaCl, TREATED WITH STH OR TTH

\begin{tabular}{|c|c|c|c|c|c|}
\hline & \multirow{2}{*}{ Group } & \multirow{2}{*}{ No. of Rats } & \multicolumn{3}{|c|}{ Organ Weights (mg./100 g. body-weight) } \\
\hline & & & Kidney & Heart & Adrenals \\
\hline I & Control & 11 & $795 \pm 24$ & $374 \pm 11$ & $14 \pm 0.34$ \\
\hline II & Thyroidectomy & 11 & $650 \pm 24$ & $283 \pm 11$ & $15 \pm 0.64$ \\
\hline III & TTH & 11 & $959 \pm 56$ & $422 \pm 15$ & $15 \pm 0.9$ \\
\hline IV & STH & 11 & $1,330 \pm 91$ & $500 \pm 22$ & $33 \pm 2 \cdot 5$ \\
\hline $\mathbf{V}$ & Thyroidectomy + TTH & 11 & $726 \pm 20$ & $322 \pm 10 \cdot 7$ & $16 \pm 0.84$ \\
\hline VI & *Thyroidectomy + STH & 12 & $705 \pm 19$ & $387 \pm 15$ & $20 \pm 1 \cdot 2$ \\
\hline
\end{tabular}

* The figures include only the eight animals killed on the 28th day, simultaneously with the other groups.

All the weights are accompanied by the standard error of the mean. 
Results

In the course of the experiment, it soon became evident that the blood pressure and the fluid intake (as well as the diuresis) rose significantly above normal only in intact rats treated with STH or TTH. Apparently thyroidectomy inhibits the salt appetite induced by STH or TTH in the intact rat (Figure).
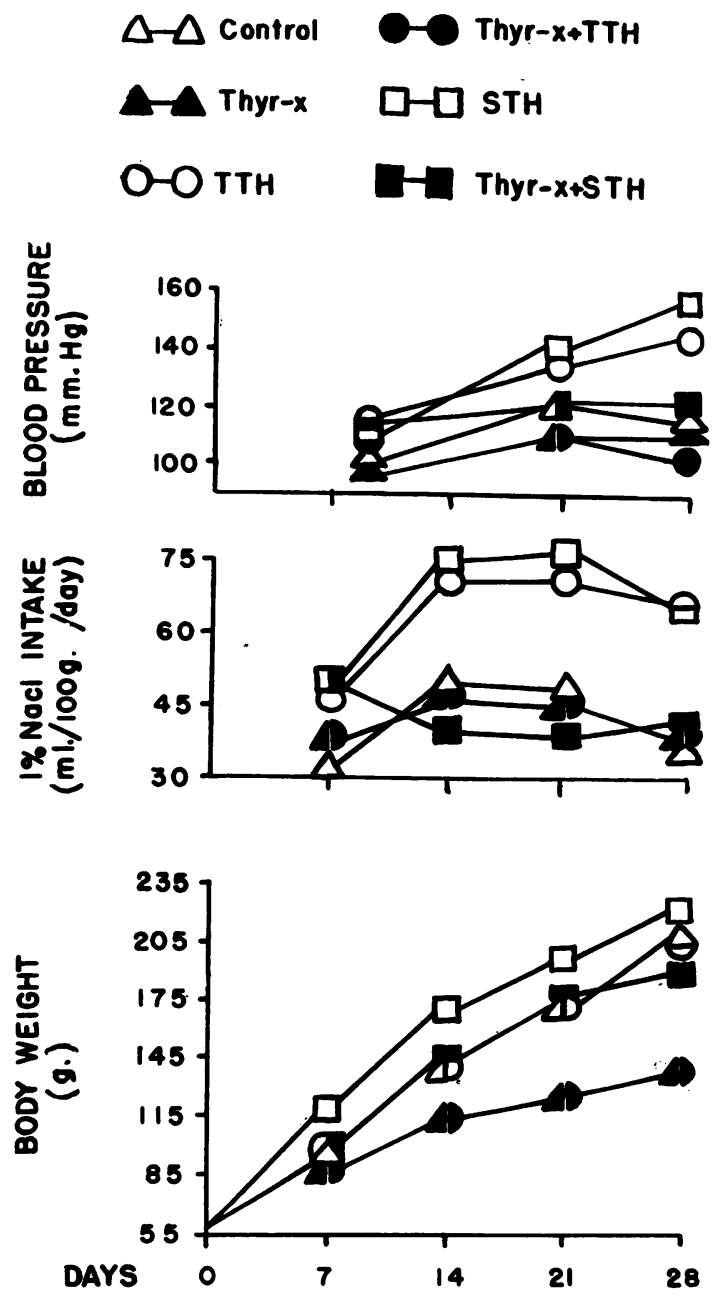

Figure.-Changes in body-weight, 1 per cent. $\mathrm{NaCl}$ intake, and blood pressure in unilaterally nephrectomized rats.

In thyroidectomized rats, the somatic weight increase was retarded in comparison with that of the intact controls; it was almost restored to normal by STH and was not affected by TTH. STH in the intact rat accelerated growth at the beginning of the experiment, whereas at the end the weight in
Group IV (STH) was not different from that in the control group (Group I). This is presumably due. to the fact that these animals showed (as we shall see later) signs of intoxication.

During the course of the experiment, two animals in Group VI (thyroidectomy and STH) showef evident manifestations of arthritis in the ankl $\overline{5}$. joint; this lasted for about 10 days and graduall tended to disappear.

At autopsy, nephrosclerosis and myocarditis werệ present only in Groups III and IV. An attempt was. made to evaluate these changes on a semi-quan $\overrightarrow{\vec{E}}$ titative basis, using a scale from + to +++ .

Table II summarizes our findings in the intact animals treated with TTH (Group III) or wit? STH (Group IV).

TABLE II

INTACT RATS TREATED WITH TTH AND STH

\begin{tabular}{|c|c|c|c|c|c|}
\hline \multirow{2}{*}{ Group } & \multirow{2}{*}{$\cdots$} & \multicolumn{2}{|c|}{ III (TTH) } & \multicolumn{2}{|c|}{ IV (STH) } \\
\hline & & $\begin{array}{l}\text { Per cent. } \\
\text { incidence }\end{array}$ & $\begin{array}{l}\text { Per cent. } \\
\text { severity }\end{array}$ & $\begin{array}{l}\text { Per cent. } \\
\text { incidence }\end{array}$ & $\begin{array}{l}\text { Per cent. } \\
\text { severity }\end{array}$ \\
\hline $\begin{array}{l}\text { Nephrosclerosis } \\
\text { Myocarditis }\end{array}$ & $\begin{array}{l}\cdots \\
\cdots\end{array}$ & $\begin{array}{l}18 \\
27\end{array}$ & $\begin{array}{r}9 \\
15\end{array}$ & $\begin{array}{r}81 \\
100\end{array}$ & $\begin{array}{l}62 \\
68\end{array}$ \\
\hline
\end{tabular}

Two animals in Group VI out of the eight kille $\$$ early (on the 28th day), and three out of the foup killed later (on the 43rd day) presented maxima lesions of periarteritis nodosa clearly visible to th naked eye. Macroscopically, the lesions consiste\& of a halo of gelatinous whitish material surrounding the mesenteric vessels and extending radially from the mesenteric ganglia to the intestinal loops.

It may be added that histological examination of the tissues confirmed the absence of lesions Groups I, II, and V. Essentially, the same differ ence as at autopsy was noted between the TTHE and the STH-treated animals (Groups III and IV) The microscopic features of the changes observed. after STH treatment do not deserve any detaile $\$$ discussion here since they have been already des ${ }^{3}$ cribed (Snedecor, 1946). We want to point ou界 that in STH-treated animals, although no lesions of periarteritis are visible at autopsy, nevertheless upo careful histological examination they can be reguro larly found in the pancreatic vessels and less constantly in the vessels of the testis.

The absence of cardiac lesions was evident in alt the thyroidectomized animals treated with ST (Group VI). Nephrosclerosis was absent in the eight animals of Group VI killed on the 28th day In the four killed later, the kidneys appeared to be normal at low magnification but, upon carefun examination, one could see an occasional glomerulu $\overrightarrow{\mathrm{P}}$ loaded with small hyaline granules and some scan 8 tubular atrophy and thickening of the basal mem $\vec{Q}$ 
branes. These alterations were slight, however, and limited to two animals. Microscopically, lesions of periarteritis nodosa were seen to be limited in all instances to the mesenteric arteries. The lesions consisted in a slight dilatation of the arteries and the presence of an abundant pleomorphic exudate invading all the coats of the artery in which neoformation of vessels could readily be seen. In some of the arteries so affected, hyaline-like material could be seen in contact with the intima of the vessel.

The mean organ weights are listed together with their standard errors in Table I.

It will be noted that the mean kidney weight was greatest in the STH-treated intact rats. TTH also induced a significant $(P<0 \cdot 01)$ augmentation of renal mass in comparison with the controls. The weight of the kidney in Group V (thyroidectomy and TTH) was almost $(P<0.02)$ significantly raised in comparison with Group II (thyroidectomy). STH did not increase the kidney mass in thyroidectomized animals $(P<0.1$ between Groups VI and II). The weight of the thyroid in the controls was $16 \pm 0.9$ and in the TTH-treated rats $23 \pm 1 \cdot 2$, the difference being statistically significant $(P<0 \cdot 01)$.

\section{Discussion}

Our results are in agreement with those of Selye (1951b), in that treatment with STH of unilaterally nephrectomized rats drinking 1 per cent. $\mathrm{NaCl}$ results in an "overdosage syndrome" which, except for the absence of macroscopic signs of periarteritis nodosa, resembles that induced by DCA in similarly prepared animals.

The inability of Friedman and others (1954) to obtain similar results with STH may be explained by taking into consideration the facts that their animals were not unilaterally nephrectomized, and did not receive 1 per cent. $\mathrm{NaCl}$ as drinking fluid, and that the dose of STH was too small. We have already shown (Salgado and Selye, 1954) that unilateral nephrectomy and a generous supply of $\mathrm{NaCl}$ are necessary conditions to obtain an "overdosage syndrome". Furthermore, with daily doses of STH less than $1 \mathrm{mg} . / 50 \mathrm{~g}$. bodyweight, hypertension, polyuria, and accompanying cardiac and renal lesions appear only inconstantly (Salgado, 1954b).

We do not intend to deal in extenso with the question of the purity of STH preparations, nevertheless we wish to emphasize the fact that in our hands TTH was unable to fully reproduce the manifestations of STH overdosage, and this fact points indirectly to the conclusion that our preparation of STH possesses capacities which cannot be explained only on the basis of the presence of TTH. It has been shown that thyroxine given to animals receiving LAP or DCA aggravates the syndrome induced by these hormones (Selye and others, 1945). On the other hand it should be recalled that a "DCA-like" syndrome can be produced in the rat by high doses of thyroxine (Selye, 1951a). It would appear then that the output by the thyroid of thyroxine-like hormones under the influence of TTH can be made responsible, at least in part, for the hypertension and the slight kidney and heart lesions obtained in this experiment by the TTH treatment of intact rats.

Thyroidectomy influences the actions of STH in a different manner. Hypertension, renal and cardiac hypertrophy (above the intact controls), myocarditis, and increased salt appetite are absent after thyroidectomy: nephrosclerosis is virtually absent and the growth-promoting activity is slightly diminished, whereas macroscopically visible periarteritis nodosa and arthritis, never obtained in intact animals, are seen after thyroidectomy. These findings are in line with our previous observations on DCA and MAD, and strongly point to the fact emphasized in our first publication on the action of DCA in thyroidectomized rats, namely that the impairment in thyroid function seems to favour the appearance of periarteritis nodosa, whereas the other symptoms of overdosage are actually diminished. It is worthwhile at this point to mention that periarteritis nodosa is not seen in intact or thyroidectomized rats receiving thyroxine and DCA (Salgado, 1954b).

The data on the hormonal production of arthritis are rather confusing. In the experimental animals included in a recent publication (Salgado, 1954a), we investigated the incidence of arthritis. This series comprised 250 animals receiving DCA in daily doses from $100 \mu \mathrm{g}$. to $10 \mathrm{mg}$. during periods of up to 4 months, and 100 treated with STH. Two animals on DCA and none of the STH-treated animals were found to have arthritis. No histological studies were made, and this fact somewhat limits the extension of our conclusions as it has been shown that at microscopic examination the percentage of arthritis seems to be much higher (Pirozynski and Akert, 1949) in similarly treated animals.

It appears, then, that spontaneous macroscopically visible arthritis is a rare finding in the intact adult rat treated with STH or DCA, and this adds significance to our small number (two) of animals with evident arthritis in the present experiment.

Selye and others (1944) claimed that arthritis could be produced with DCA in the intact rat and more easily if the animals are thyroidectomized or adrenalectomized, but their series of animals was far too small, and infection should have been taken 
into consideration in the evaluation of the results as many of their animals died from pneumonia. It has been shown that DCA produces arthritis in the rat only if the animals are thyroidectomized or have lesions in the adrenals (Harrison, 1951; Harrison and Barnett, 1953). Finally, Reinhardt and Li (1953) produced joint lesions with STH in adrenalectomized-castrated rats. It is possible, then, that the common trait between the results of Harrison and Barnett, Reinhardt and $\mathrm{Li}$, and our own is a suppression of some antiphlogistic power of the adrenal after thyroidectomy. It is worthwhile to mention that aggravation of rheumatoid arthritis has been reported in man following thyroidectomy (Traut, 1952; Laine and others, 1954).

These experiments should be repeated in rats thyroidectomized with radioactive iodine in order to rule out a possible, though improbable, participation of the parathyroid gland.

\section{Summary}

The effect of overdosage with STH or TTH has been studied in intact and thyroparathyroidectomized rats, unilaterally nephrectomized and drinking 1 per cent. $\mathrm{NaCl}$.

STH in the intact rat induces hypertension, nephrosclerosis, polyuria, myocarditis, and renal, cardiac, and adrenal enlargement. TTH under the same conditions induces slight lesions and enlargement in kidney and heart, polyuria, and hypertension. In thyroparathyroidectomized rats all these effects of TTH are abolished except for minimal renal and cardiac enlargement. STH induces periarteritis nodosa and arthritis, adrenal, cardiac, and renal enlargement, and slight lesions in the kidney. The other manifestations seen in the intact animal are absent.

These results are briefly discussed.

These investigations were subsidized by a grant from the Gustavus and Louise Pfeiffer Foundation and the Warner-Chilcott Laboratories. The author is also indebted to Dr. S. L. Steelman of the Armour Laboratories, Chicago, U.S.A., for the generous gift of the TTH used in this experiment.

\section{REFERENCES}

Friedman, M., and Freed, S. C. (1949). Proc. Soc. exp. Biol. (N.Y.), 70, 670 .

Friedman, S. M., Nakashima, M., and Friedman C. L. (1954). Canad. J. Biochem. Physiol., 32, 200.
Harrison, R. G. (1951). Brit. med. J., 2, 1299. 12, 275 . Vainio, K. J., and Holopainen, T. E. (1954). Ibid. 13, 250 .

McManus, J. F. A. (1948). Amer. J. Path., 24, 643.

Pirozynski, W., and Akert, K. (1949). Schweiz. med. Wschr. 79, 745.

Reinhardt, W. O., and Li, C. H. (1953). Science, 117, 295.

Salgado, E. (1954a). Endocrinology, 55, 377. Inst. Méd. and Chir. Expér., Université de Montréal. and Selye, H. (1954). J. Endocr., 11, 331.

- (1955). J. Lab. clin. Med. In the press.

Selye, H. (1951a). Rev. Canad. Biol., 9, 475.

(1951b). Brit. med. J., 1, 263.
Stone, H., Nielsen, K., and Leblond, C. P. (1945). Canad.

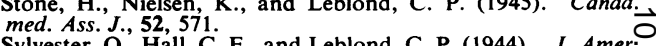

Sylvester, O., Hall, C. E., and Leblond, C. P. (1944). J. Amer:-
med. Ass., 124, 201.

Snedecor, G. W. (1946). "Statistical Methods Applied to Experi $\overrightarrow{\vec{C}}$ ments in Agriculture and Biology", 4th ed. Iowa State College Press, Ames, Iowa.

Traut, E. F. (1952). "Rheumatic Diseases". Mosby, St. Louis.

Action des hormones de croissance et thyréotrope chez des rats thyroïdectomisés

RÉSUMÉ

On étudia l'effet des doses excessives d'hormones somatotrope (STH) et thyréotrope (TTH) sur des ratsintacts et sur des rats privés de leur thyroïde, paraz thyroïde, d'un rein et buvant une solution de $\mathrm{NaC}$ à $1 \%$.

La STH chez des rats intact produit de l'hypertension ${ }_{2}^{-}$ nephrosclérose, polyurie, myocardite et hypertrophieo rénale, cardiaque et surrénale. La TTH dans les mêmeš circonstances produit des lésions mineures et une aug:mentation de volume du rein et du coeur, polyurie ef hypertension. Chez des rats thyréoparathyréoprives tous ces effets de la TTH sont abolis, à l'exception d'une hypertrophie minime du coeur et du rein. La STH produit la périartérite noueuse et l'arthrite, l'hypero trophie surrénale, cardiaque et rénale et de légèrę lésions rénales. Les autres manifestations observés che les animaux intacts sont absentes.

On discute brèvement ces résultats.

Acción de las hormonas de crecimiento y tireotrópica en ratas tiroidectomizadas

\section{Sumario}

Se estudió el efecto de dosis excesivas de hormonas somatotrópica (STH) y tireotrópica (TTH) en ratas. intactas y en tireoparatiroidectomizadas, nefrectomizadå unilateralmente y bebiendo $\mathrm{NaCl}$ al 1 por ciento.

STH en ratas intactas causa hipertensión, nefroeo sclerosis, poliuria, miocarditis e hipertrofia renal? cardiaca y suprarrenal. TTH en las mismas condiciones causa lesiones leves y hipertrofia renal y cardiaca, poliuriq. e hipertensión. En ratas tireoparatiroidectomizadas todos estos efectos de la TTH están abolidos con excepor ción de una hipertrofia renal y cardiaca mínima. STH causa periarteritis nodosa y artritis, hipertrofia suprare renal, cardiaca y renal leve y ligeras lesiones en edJ riñón. Las demás manifestaciones observadas ęr animales intactos están ausentes.

Se discute brevemente estos resultados. 